\title{
Impact of curative surgery on bone in a patient with osteitis fibrosa cystica of primary hyperparathyroidism
}

\author{
Samantha Sathyakumar, ${ }^{1}$ Kripa Elizabeth Cherian, $^{2}$ Sahana Shetty, ${ }^{3}$ \\ Thomas Vizhalil Paul ${ }^{3}$
}

'Department of Endocrinology, Diabetes \& Metabolism, Christian Medical College, Vellore, Tamil Nadu, India 2Department of Endocrinology, Christian Medical College, Vellore, Tamil Nadu, India ${ }^{3}$ Christian Medical College, Vellore, Tamil Nadu, India

\section{Correspondence to}

Professor Thomas Vizhalil Paul, thomasvpaul@yahoo.com

Accepted 11 March 2016

\section{CrossMark}

To cite: Sathyakumar $S$, Cherian KE, Shetty $\mathrm{S}$, et al. BMJ Case Rep Published online: [please include Day Month Year] doi:10.1136/ bcr-2016-214970

\section{DESCRIPTION}

A 28-year-old woman presented with bone pains and progressive proximal muscle weakness of 2 years duration. Examination revealed significant bony tenderness over the spine and both hips and severe proximal muscle weakness in the lower limbs. The rest of the examination was normal. Biochemical evaluation showed parathyroid hormone (PTH)-dependent hypercalcaemia (serum calcium $12.4 \mathrm{mg} / \mathrm{dL}$ (normal 8.4-10.2); PTH $>1900 \mathrm{pg} / \mathrm{mL}$ (normal 8-50)). Remaining blood bone biochemistry was as follows: phosphorus $2 \mathrm{mg} / \mathrm{dL}$ (normal 2.5-4.5), alkaline phosphatase $1112 \mathrm{U} / \mathrm{L}$ (normal 40-125), creatinine $0.9 \mathrm{mg} / \mathrm{dL}$ (normal 0.6-1.2) and 25 hydroxy vitamin D $12.5 \mathrm{ng} / \mathrm{mL}$ (normal 30-75). A skeletal survey performed was diagnostic of osteitis fibrosa cystica with multiple cystic lesions secondary to brown tumours in the pelvis and femoral bones (figure 1A). A marked reduction in bone mineral density (BMD) was seen at all sites (figure 2). There was no evidence of renal stones. A technetium-sestamibi uptake scan revealed a lesion in the left superior parathyroid (figure 3 ). Thus the patient was diagnosed as having severe hyperparathyroidism secondary to parathyroid adenoma and vitamin D deficiency. She was treated with hydration and cholecalciferol. She underwent a focused parathyroidectomy following which her calcium normalised and histopathology was consistent with a parathyroid adenoma. She was continued on vitamin D supplementation. She made a remarkable improvement after surgery and was asymptomatic with neither bone pain nor muscle weakness at the end of 1 year. Her serum calcium was $8.6 \mathrm{mg} / \mathrm{dL}$. There was normalisation of BMD at two sites and remineralisation of lytic lesions in the pelvis and femur (figures 1B, C and 2).

Skeletal lesions associated with hyperparathyroidism account for a large part of the morbidity associated with this condition. However, with the advent of routine screening for calcium levels, advanced disease has become uncommon in the Western population. On the contrary, overt manifestations of hyperparathyroidism including osteitis fibrosa cystica, renal stones and pancreatitis, continue to be seen in developing countries such as India. ${ }^{1}$ Brown tumours seen in osteitis fibrosa cystica commonly affect the tibia, femur, pelvis, vertebrae, ribs and mandible. After successful parathyroidectomy, recovery of bone mass occurs earlier at sites with cancellous bone as compared with those of cortical bone. ${ }^{2}$ 

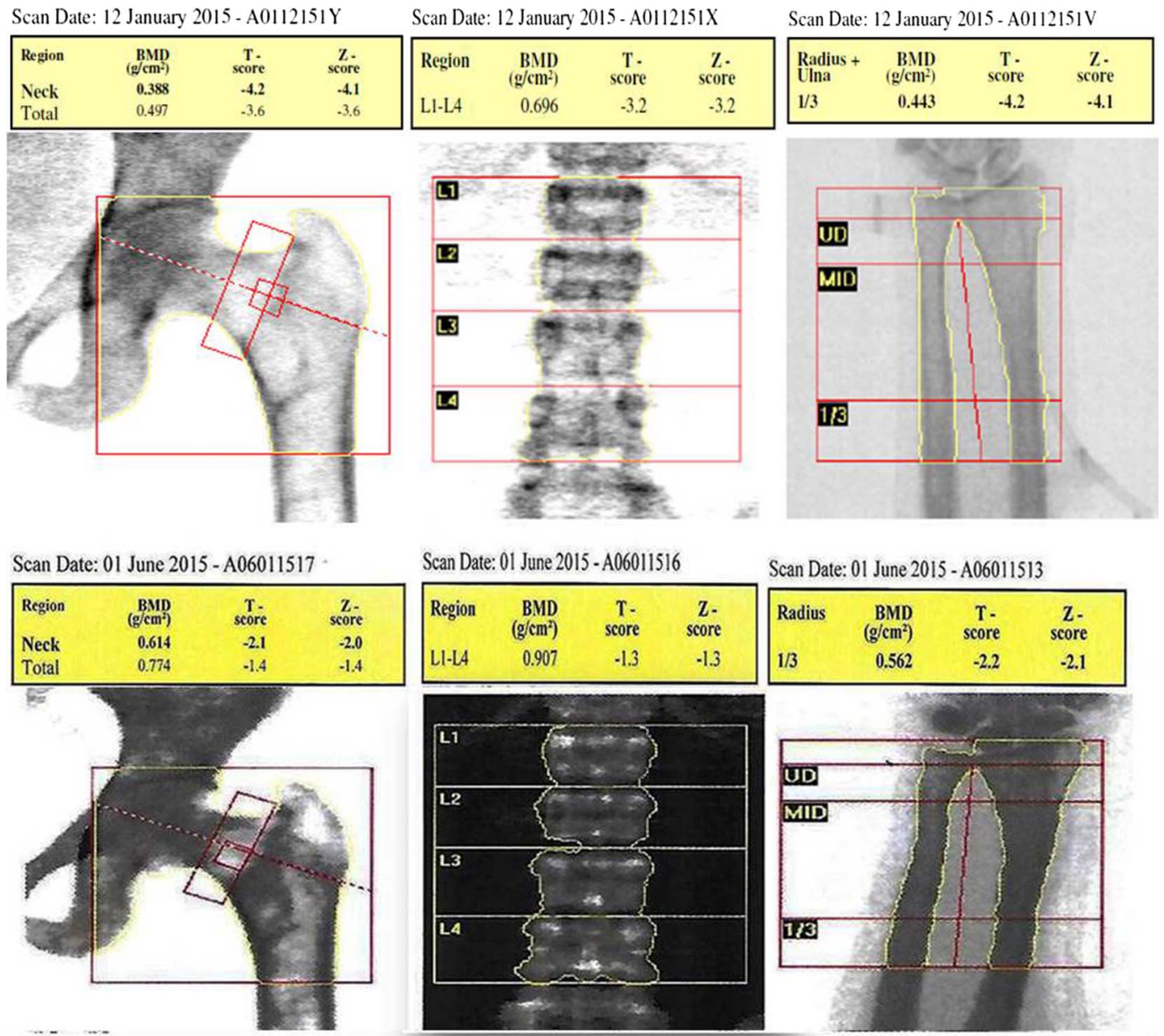

Scan Date: 01 June 2015 - A06011516

\begin{tabular}{|c|c|c|c|}
\hline \multicolumn{4}{|c|}{ Scan Date: 01 June 2015 - A06011513 } \\
\hline Radius & $\underset{\left(\mathrm{g} / \mathrm{cm}^{2}\right)}{\mathrm{BMD}}$ & $\begin{array}{c}\mathrm{T} \text { - } \\
\text { score }\end{array}$ & $\underset{\text { score }}{\text { Z- }}$ \\
\hline $1 / 3$ & 0.562 & -2.2 & -2.1 \\
\hline
\end{tabular}
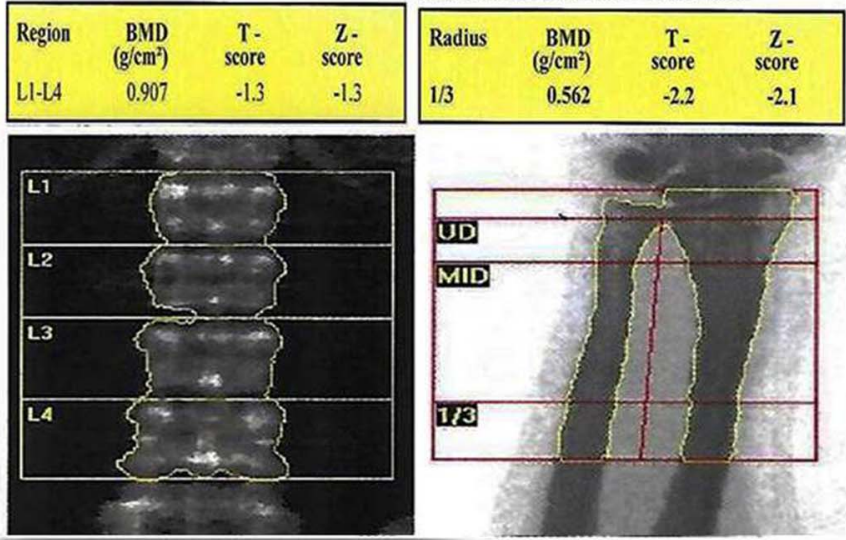

Scan Date: 05 January 2016 - A0105164E

\begin{tabular}{|c|c|c|c|}
\hline Region & $\begin{array}{c}\text { BUDD } \\
\left(g^{\prime} / \mathrm{cm}^{2}\right)\end{array}$ & $\underset{\text { score }}{\mathrm{T} \text {. }}$ & score \\
\hline Neck & 0.989 & 1.3 & 1.3 \\
\hline Total & 1.1.166 & 1.8 & 1.9 \\
\hline
\end{tabular}

\begin{tabular}{|c|c|c|c|c|c|c|c|}
\hline \multicolumn{4}{|c|}{ Scan Date: 05 January 2016 - A0105164C } & \multicolumn{4}{|c|}{ Scan Date: 05 January 2016 - A01051649 } \\
\hline Region & $\underset{\substack{\text { BMD } \\
\left(\mathrm{g} / \mathrm{cm}^{2}\right)}}{\text { ) }}$ & $\begin{array}{c}\mathrm{T} \text {. } \\
\text { score }\end{array}$ & $\begin{array}{c}\text { Z. } \\
\text { score }\end{array}$ & Radius & $\underset{\left(\mathrm{g} / \mathrm{cm}^{2}\right)}{\mathrm{BMD}}$ & $\begin{array}{c}\text { T- } \\
\text { score }\end{array}$ & $\underset{\text { score }}{\text { Z- }}$ \\
\hline LI-LA & 1.063 & 0.1 & 0.1 & $1 / 3$ & 0.616 & -1.3 & -1.2 \\
\hline
\end{tabular}
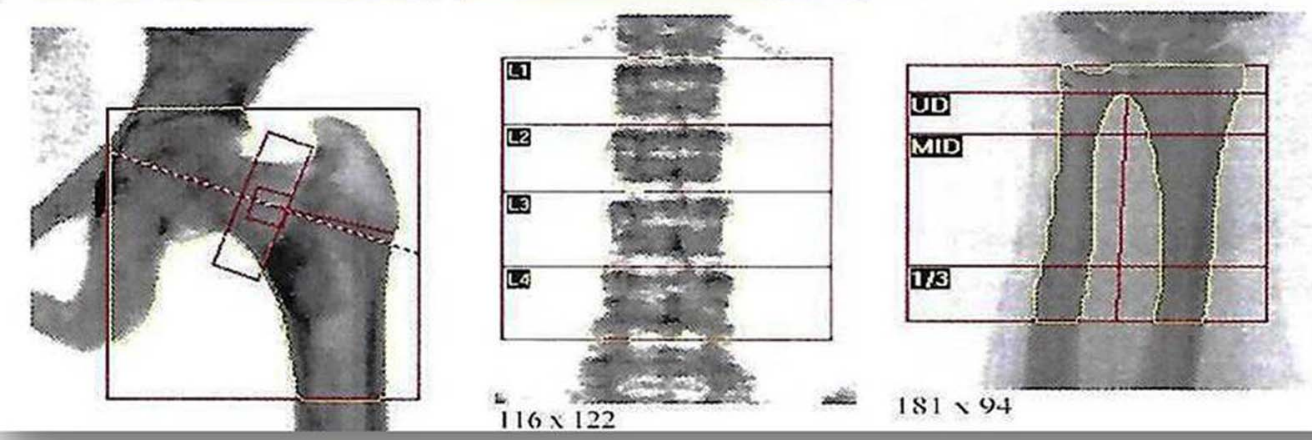

Figure 2 Bone mineral density (BMD) before and 6 months and 1 year following parathyroidectomy.

Figure 3 Sestamibi scan showing left superior parathyroid adenoma.

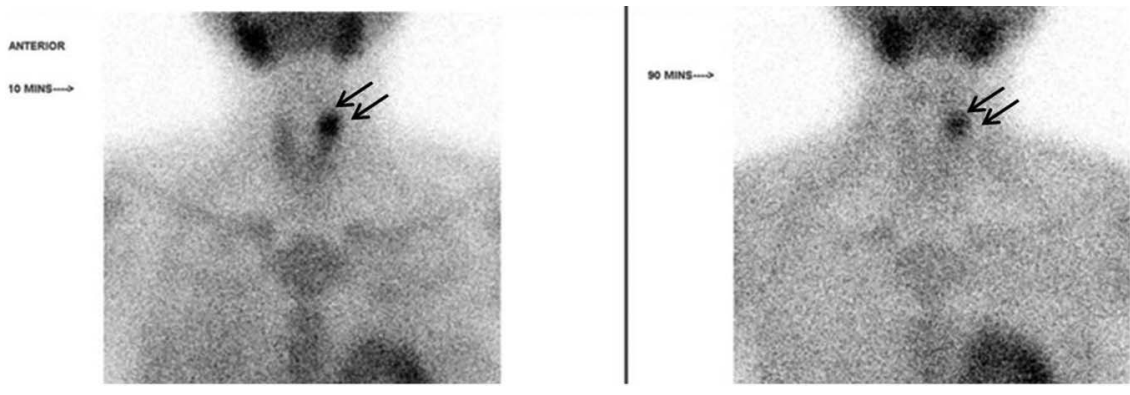

Sathyakumar S, et al. BMJ Case Rep 2016. doi:10.1136/bcr-2016-214970 


\section{Learning points}

- Overt manifestations of primary hyperparathyroidism including osteitis fibrosa cystica, renal stones and pancreatitis continue to be seen in developing countries such as India.

- Severity of the bone disease in primary hyperparathyroidism is further aggravated by coexisting vitamin D deficiency.

- Brown tumours seen in osteitis fibrosa cystica commonly affect the tibia, femur, pelvis, vertebrae, ribs and mandible and parathyroidectomy is the definitive treatment of hypercalcaemia secondary to primary hyperparathyroidism and can dramatically improve osteitis fibrosa cystica.
Acknowledgements The authors thank Dr Deepak Abraham for surgical management; Dr Julie Hepzibah for the Nuclear Medicine imaging; Ms Banu Shankar for secretarial help.

Contributors SS, KEC and SS wrote the manuscript. SS, KEC, SS and TVP reviewed and approved the manuscript.

Competing interests None declared.

Patient consent Obtained.

Provenance and peer review Not commissioned; externally peer reviewed.

\section{REFERENCES}

1 Mishra SK, Agarwal G, Kar DK, et al. Unique clinical characteristics of primary hyperparathyroidism in India. Br J Surg 2001;88:708-14.

2 Kulak CA, Bandeira C, Voss D, et al. Marked improvement in bone mass after parathyroidectomy in osteitis fibrosa cystica. J Clin Endocrinol Metab 1998;83:732-5.

Copyright 2016 BMJ Publishing Group. All rights reserved. For permission to reuse any of this content visit http://group.bmj.com/group/rights-licensing/permissions.

BMJ Case Report Fellows may re-use this article for personal use and teaching without any further permission.

Become a Fellow of BMJ Case Reports today and you can:

- Submit as many cases as you like

- Enjoy fast sympathetic peer review and rapid publication of accepted articles

- Access all the published articles

- Re-use any of the published material for personal use and teaching without further permission

For information on Institutional Fellowships contact consortiasales@bmjgroup.com

Visit casereports.bmj.com for more articles like this and to become a Fellow 